\title{
Colon Traditional Serrated Adenoma
}

National Cancer Institute

\section{Source}

National Cancer Institute. Colon Traditional Serrated Adenoma. NCI Thesaurus. Code C43577.

An adenoma that arises from the colon. It is characterized by prominent serration of the glands and the presence of generalized low-grade dysplasia. 